\title{
REFORGING SPATIAL IDENTITY FOR SOCIAL SUSTAINABILITY
}

\author{
R. BARELKOWSKI \\ West-Pomeranian University of Technology in Szczecin.
}

\begin{abstract}
Spatial conditions cannot fully determine the quality of social or human life, but are significant factors influencing both the present and the future. The spatial aspect of the city is always accompanied by other aspects, more ephemeral, intangible, yet detectable and socially active. Thus, the condition of social identity is related to the spatial identity used by a particular community.

A small-scale community of about 14,000 people lives within an agglomeration of Poznan in the Rokietnica administrative area. Its very core, once a large farming complex, located at the heart of the town, is almost void in terms of urban structures and continuity of urban tissue. This gap is 12 hectares large and is exactly equidistant from the main existing and significant objects: multipurpose/sports hall, commercial center, the set of local authorities, the church, primary and secondary schools, among others.

Filling this large area is a unique task and to assure social sustainability it cannot be performed otherwise than with social participation. The paper will present the application of spatial planning and urban design efforts implementing multiple stage social participation and the experience from the first, conceptual, programmatic project. Its ultimate goal—new Rokietnica center for citizens and renewed spatial identity.

Keywords: social sustainability, spatial identity, spatial planning, sustainability.
\end{abstract}

\section{INTRODUCTION}

Rarely an undertaking of creating a town center occurs in Europe, where the urban development has been so strong for so many centuries. The main network of cities, towns, and villages is already established, and its supplementation comes in the form of expansions or annexes to existing structures. While this means that the present is expected to correct the errors of the past and adapt to the future, the ongoing processes of urban improvement relies on gradual progress of the city (or the settlement). Slow but sure process of accommodating social, technological, and spatial changes is as optimal as it can be taking into account various factors responsible for establishing the quality of urban life-and it strongly profits from historical accumulation of meanings, establishing community habits related to spatial configuration, influencing envisioning of mental maps by the members of the community, thereby contributing to the very significant aspect of urban environment, which connects people to the places they live in $[1,2]$. Working on spatial identity in such places focuses on subtle corrections, refurbishment, and gradual synergic actions [3].

Rokietnica, a community located within the limits of agglomeration of the city of Poznan, is a different case. Evolving from rural settlement for several centuries it did not produce a visible and comprehensible center, which could play a role of an integrating node for a growing population. Located on flatlands, rarely sculpted by post-glacial formations, it has its housing mainly developed along principal routes leading from Tarnowo Podgorne to 
Oborniki, and from Poznan to Szamotuly. The central part of the village was once arranged as a noble's mansion with accompanying buildings and farm buildings, but this orderly cluster of buildings has been substantially diminished, and the mansion itself is almost a sole remaining witness of the glory of the past. Socialist/communist times brought conversion into collective farming that was governed and managed by the administration, resulting in the loss of connection between the community and owned property, and ultimately in today's total destruction of material components that once constituted the farm infrastructure. Interestingly, a significant part of the area, which totals around 12 ha, is located along the trench that once held the stream collecting waters from nearby fields. Contemporarily only the small pond remains, with the level of water far below the surrounding terrain, but clearly mirroring relatively high soil waters. This particular disadvantage is a direct consequence of a communist administration's ill-fated decision to improve everything what 'the wrong' past has brought - the drainage system, once operational, has been badly damaged and currently causes difficulties at every building enterprise undertaken in the area.

The case of Rokietnica will provide the insight into how special conditions of center founded in cruda radice alters sustainability standards, if it does at all.

\section{THE SUSTAINABLE CONDITIONS FOR COMMUNITY GROWTH}

While this paper focuses on the example of Rokietnica, it is important to relate it to the generic case of settlements missing features of central urban structures. It is quite obvious that a central location does not guarantee adequate significance and does not imminently encourage the accumulation of necessary and appropriate services and infrastructure. Thus, unattended, the process of generation of the center is usually far from being efficient and leads to several deficiencies that impede the sustainable development of a local communityit is not the lack of center itself, but the absence of several key features of built environment this particular state depicts (with the lacking center being at the same time one of the causes and strong symptoms).

The local center acts as a specific node within an urbanized space. There are several tasks, and the so-called center is expected to deliver the majority of the below-mentioned functions [4]:

1. The availability of distinguished urban functions (administrative, commercial, cultural, etc.),

2. The accessibility, being socially rated between optimum and average,

3. The integrative potential —exemplified by public spaces and/or public or cultural institutions (buildings) located assuming that they are able to and that they do perform related tasks,

4. Balanced flexibility,

5. Higher saturation of nonresidential functions,

6. Established reference point (stability node) combined with safety,

7. Visual recognition—-spatial identity build.

The term 'social sustainability' has a wide variety of meanings exceeding the abovementioned list, but in the case of a settlement center seen as physical urbanized space its application may be limited to those key elements. Availability is related to the presence of significant functions or objects. These objects may be different, but they should relate and reinforce social ties, improve social comfort or attractiveness, or serve local 
community-having a permanent or frequent link to common life of community itself. Accessibility means not only to allow community members to get there (and back) to the center easily, but to be handicapped persons-friendly, and to provide orientation and easy access to diverse facilities. Integrative potential corresponds to connectivity and direct identity reinforcement (or creation in cases there is no identity prior to intervention). Balanced flexibility stands for flexibility in opportunities to use a particular space, but at the same time maintaining balance in its fluctuations, transformations, where changes are moderated to assure possible future developments and adjustments according to unpredictable patterns of social expectations [5]. In times of globalization this seeming paradox appears to expose itself even stronger, seeking explicit or implicit connection between abstracts and solid spaces [6]. The saturation of nonresidential functions is meant to facilitate the process of attracting users - community members, and offer extended opportunities to exchange information, provide or receive services, perform sports and recreation activities, profit from cultural services, among others. This is intended to act as a site (or area) to fulfill human expectations of social paradox of parallel requirements of stability and change; safety, but in evolving; and thus unable to eliminate risks impossible to fully anticipate [7]. The center of the settlement is expected to build visual representation of what community sees as their aspirations to found their integrity on, and how the image of the community is represented in an urbanized space.

\section{THE THEATRE OF EVENTS}

The central part of Rokietnica is developed along its main roads connecting Poznan with major towns of its second settlement circle, in this case particularly Szamotuly, Wronki, Oborniki, Tarnowo Podgorne. One of the roads leads from Oborniki via Zlotniki to Rokietnica and further to Tarnowo Podgorne. This route provides the northern and western borders of the site, in some places offset by random buildings, mostly of rural type or detached single family houses. Another road leads from Poznan going parallel to the main railway line (PoznanSzczecin) and diagonally from southeast to northwest. Another road connects Poznan with Szamotuly marking the southern limits of the 12 ha area. The latter leads through the area of higher density of housing, introduced in the second half of the first decade of 21 st centurymainly 3 level multiapartment housing designed in a typical suburban manner of geometric repetitive and anonymous space.

The area around the site is almost flat, but as mentioned above the site itself has several clearly visible features - a large pit with a pond, with extremely steep slopes, several points recognizable as former backwaters, now dried, but still maintaining high saturation with ground waters, line of high poplars indicating trench where once water flew, and significant wedge distinguishing the eastern part of the area, located higher, separated and evidently forming a section of the area detached and destined to accommodate different functional profile than the remaining, more privileged part. The main component of the area touches two regional roads to the north and to the south, being irregular, someplace wider, especially to the north, in other places more narrow. The northern plateau falls to the south reaching its lowest level in the middle distance between the mentioned roads and then slightly rising to fall again and expose the stream, continued outside of the analyzed space, south of the road to Szamotuly (Trakt Napoleonski).

Recently, the buildings once existing in this area has been demolished providing space for new developments, one of which already introduced and, unfortunately, due to land ownership geometry, standing in the way of the most apparent possible northern entry to the area. 
A study on spatial development including the conditions and encouraged processes expected in the environment has undertaken the problem of the area, distinguishing three different zones: the North Zone, the South Zone, and the East Zone. The study tackled multiple actual problems and aimed at providing more flexible and multiple scenario-oriented mechanisms allowing for longitudinally and more meticulous planning within strategically important zones. A planning team has introduced methodological approach leading to several key concepts being approved and implemented successfully by local authorities between 2010 and 2014-it is scenario-based planning, unification of planning conceptual system, standardization of master plans, but the most significant was the ideological contribution laid by the preamble of the study: mainly the concept of flexible spaces, anti-sprawl policies, and establishing nonexistent spatial identity, which should rely on reforging the concept of bedroom community (dormitory town) into a fully self-conscious and distinct community, with independent assets and an autonomous potential to develop.

The central area in the main settlement (among total of 17)—Rokietnica-was seen in the study as beneficial to convey those ideological, programmatic, and social concepts. It was defined as an area of multithreaded development, giving the authorities many possible ways to deal with this temporarily void area. Prototype solutions opened multiple perspectives including the concept of continual space of single family houses (abandoning the idea of local center), strong densification of multifamily buildings, and various concepts of center starting from multiapartment buildings with commercial space and services located on the ground floor, through mixed-use, to the prevalence of services and extensive recreational infrastructure aimed to profit from a significant percentage of greening in the area.

\section{PLANNING FOR SPACE OR PLANNING FOR COMMUNITY}

There is a fundamental difference between the conceptual aspect of making space livable and sustainable, and technical or procedural approach as established by the legal framework, and fulfilling the ideological assumptions within planning requires some significant interpretation skills and mechanisms that go beyond what is usually expected from the administration - as practical implementation requires acting with real plan or study, and cooperating with local authorities to be able to observe applied methodologies at work.

According to what was presented in 2012, the framework to establish sustainable suburban development postulated the application of a strategy for the edge of the city [8]. The scheme involved six main components of sustainability: reduction of resources consumption (RRC), prioritizing urban development (PUD), adaptability of urban nodes (AUN), integrity of urban tissue (IUT), proportions among types of spaces (PTS), and coordinated management and development (CMD). Despite the information policies and evident link between the local communities, as it can be easily discerned, only half of the above-mentioned elements are directly perceived by the members of local communities, while the remainder is related to policy and organization imposed by the authorities. While the AUN, IUT, and PTS are influencing experiences of people, RRC focuses on global resource balances being quite far from individual understanding of energy savings. The PUD and CMD are related to decision making and then to the implementation of selected guidelines, not necessarily resulting in detailed analysis of social preferences, ordering of preferences of the community, and creating permanent mechanisms of confidence and additive continuity between authorities and the community, which most often results in social participation. It is important to notice, however, that legal reference for planning activity privileges legal approach to conceptual/ ideological approach, and thus may miss the purpose with tools serving the implementation 
and execution of the purpose [9]. Therefore, the social component in the PRS method is always recommended and the multiple benefits from social participation including early conflict recognition, information exchange (communication of planning process, its limitations, entitlements, and benefits), and particularly in the ultimate goal behind a satellite type of urban structure which is either the creation of an autonomous identity or reinforcing this identity by spatial means.

The strategy has been furthermore developed and presented while researching less complicated cases within the agglomeration of Poznan, although the case of Rokietnica was not directly analyzed [10]. This time the center of Rokietnica has become a major issue-the process of development of nearby areas convinced the local authorities to act in order to secure controlled and harmonious arrangement of this strategic site. As explained above, the principal idea of the intervention is related to today's perception of community identity-this conclusion has been made clear with the results of inquiry assessment. But the research team got it clear that there are more tasks and more problems to be solved: increasing development activities, counter-balancing the inflation of urban structures, local discontinuity of urban tissue, and opportunity to consolidate multiple living aspects-living, working, shopping.

It seems possible to achieve appropriate results of urban transformation without the community, but the risk of misplacing the goals of such transformation is quite high and there are no benefits of getting the community involved in the process. As this kind of relationship (or lack of) results are unpredictable, the inclusion of community support and feedback is indispensable. For the Rokietnica center, the research program assumed three alternative spatial solutions, but spatial solution was programmatically meant to be the end product of a socially engaging process, starting with primary recognition of community preferences, concepts, and spatial identity recognition in the first inquiry, then preparation of primary programs for the center, followed by inducing public discussion with the inclusion of local media, public meetings, and ultimately the second inquiry performed in cooperation with another university, the Adam Mickiewicz University in Poznan. While the research team prepared the questions for the inquiry, AMU team elaborated an interactive platform to allow respondents to use information and telecommunication technology to provide their feedback, referencing implementations of participatory public GIS in Seattle and Toronto [11].

Public consideration of a spatial shape of the center, undetermined and presented as the subject of social consensus on the programmatic component of this specific planning process, has led to both the emergence of identity issue and clash between competing visions of what the center of Rokietnica should become. Particularly, older inhabitants of the commune prioritized the strategy of blending (continual tissue of low, mainly single family, houses mixed with some public and commercial services), but the significant majority opted for stronger manifestation of central properties of the site, indicated three-floor and higher buildings as more appropriate, and generally accepted necessary increase in saturation of the area, even higher to bargain more recreation and greening areas in exchange for incentives for developers. It became possible to adjust the preliminary programming of the area and elaborate three different visions for the site - entitled to facilitate connection between members of community with different scenarios proposed as alternatives. Instead of a preservative approach leading to a strategy of blending, the strategy of reconfiguration has been approved (Table 1 and 2). The table of impacts has been generated accordingly to distinguish the case from other cases researched previously.

The idea of independent performance of Rokietnica urban environment relied on several assumptions related to cultural content and spatial semantics, functional profile, day cycle imprint, and environmental output. 
44 Urban Regeneration and Sustainability

Table 1: Sustainability indicators and its impact: Rokietnica center.

Groups of indicators /properties/

interactions

Strategy (rate of impact)

\section{Strategy type}

autonomous economic potential

autonomous social potential

accessibility and connectivity

local center $<>$ city core

accessibility and connectivity

local center $<>$ other local

centers

accessibility and connectivity

local center $<>$ cultural/leisure/ commercial quarters (nodes)

environmental capacity and potential of self-recovery

environmental impact

impact on nearby

communities-mutual

interactions and influences

cultural

(urban) form related-

harmonious space

\section{reconfig}

average to high

(usually average, but due to central location of the area may result in high potential)

high

(this is particularly suited to exemplify the power of central zone of the settlement or town)

average to high

(close location of railway station assures easy access to basic and quick transport between the center and the downtown of the agglomeration)

high

(privileged location, multiple possible connections despite apparent problems for traffic organization may improve the usual average result)

low to none

(nonapplicable due to lack of cultural quarters outside of the area (and the area is expected to develop cultural function in time), low due to limited access to cultural infrastructure in the agglomeration)

low to average

(there is significant amount of greenings in the area; however, the area has little to no connection to other green areas - the only one with external links is the terrain to the south)

average

(despite the significant impact on the environment the area is located at the heart of urbanized district and, therefore, negative environmental

average

(contrary to usual high impact this abandoned and unused area converted will not dramatically affect the spatial comfort, but definitely will affect the way of life, and the quality will improve)

average (the center not only presents an opportunity to introduce cultural function, but existing elements in the vicinity are improved due to better accessibility and connections)

$\mathrm{n} / \mathrm{a}$ 
Groups of indicators /properties/

\begin{tabular}{ll} 
interactions & Strategy (rate of impact) \\
\hline (urban) form related—-safety & $\mathrm{n} / \mathrm{a}$ \\
(urban) form related-local com- & $\mathrm{n} / \mathrm{a}$ \\
fort & \\
(urban) form related—adaptability & $\mathrm{n} / \mathrm{a}$ \\
(urban) form related—integrity & $\mathrm{n} / \mathrm{a}$
\end{tabular}

n/a - nonapplicable

Table 2: Strategy profile.

\begin{tabular}{|c|c|c|}
\hline \multirow{2}{*}{$\begin{array}{l}\text { Profile } \\
\text { element }\end{array}$} & \multirow{2}{*}{$\begin{array}{l}\text { Element } \\
\text { interpretation }\end{array}$} & Strategy (rate of impact) \\
\hline & & reconfig \\
\hline identity (ID) & $\begin{array}{l}\text { meaning / cultural } \\
\text { content }\end{array}$ & average to high \\
\hline $\begin{array}{l}\text { mono vs multifunctionality } \\
\text { (SF vs MF) }\end{array}$ & $\begin{array}{l}\text { users } \\
\text { (also PTS) }\end{array}$ & $\begin{array}{l}\text { MF } \\
\text { average to high variety of } \\
\text { users }\end{array}$ \\
\hline day cycle (DC) & program / flow & full complex \\
\hline environmental output (EO) & $\begin{array}{l}\text { parametric performance } \\
\text { (e.g. emissions) }\end{array}$ & mixed guidelines \\
\hline
\end{tabular}

As it appears the concept of town/settlement center imposes different or increased strength effects on space and its properties: the stronger and more positive, the more interaction with the local community reflects a conclusive vision of the area. Previously, a research team had an opportunity to acknowledge the patterns of developments in Kiekrz, also implementing a reconfiguration strategy. However, while in the latter case urban tissue was devoid of commercial space required to serve the community, and it had to be remodeled and supplemented with the local center, becoming a yet new coherent element of local identity which is expected and required by the local community, in the former one (Rokietnica) the significance and the scale of intervention is drastically larger, making the range of possible impacts and effects much wider (Table 3).

Spatial effects of the intervention and potential (spatial) identity build have been tested in three alternative designs becoming another subject of social consultancy oriented toward elaboration of a final proposal, the most relevant to what is the resultant of multiple factors diagnosed during the execution of the program. These three alternatives proposed diverse configurations of public spaces, discussed different locations of important public buildings and facilities, and adopted various typologies of common buildings' infill. The first of the projects assumes the construction of traditional European quarter-like components, which in the case of Rokietnica had to be slightly adjusted because of narrow areas and limited quarter depth. The core of this concept was constituted by a central urban square, rectangular in shape and programmed to host public events, feasts, exposing the hierarchy of gradually culminated space. The second project assumed more streamlined public space in the shape of 
Table 3: Strategy program and benefits.

\begin{tabular}{|c|c|}
\hline Area no. & Area 16 \\
\hline Area name & Rokietnica Center \\
\hline Strategy & reconfiguration \\
\hline Neighboring structures & mixed use \\
\hline Users & average variety \\
\hline Program & $\begin{array}{l}\text { mixed-use > } \\
\text { primary: residential (multiapartment housing), commercial, } \\
\text { retail } \\
\text { secondary: sports and recreation, cultural, offices, adminis- } \\
\text { trative }\end{array}$ \\
\hline Parametric performance & significant increase \\
\hline $\begin{array}{l}\text { Instrumentalization } \\
\text { of planned solutions } \\
\text { (priorities) }\end{array}$ & $\begin{array}{l}\text { reduction }(\mathrm{RRC}) \\
\text { prioritizing (PUD) } \\
\text { adaptability (AUN) } \\
\text { integrity (IUT) } \\
\text { proportion (PTS) }\end{array}$ \\
\hline RRC & $\begin{array}{l}\text { providing basic services at comfortable distance, consoli- } \\
\text { dating the use of infrastructure, improving urban space use } \\
\text { (positive densification }\end{array}$ \\
\hline PUD & $\begin{array}{l}\text { strong incentive to develop high to average density of hous- } \\
\text { ing }\end{array}$ \\
\hline AUN & high potential of adaptability \\
\hline IUT & restoring dispersed structure of Rokietnica \\
\hline PTS & $\begin{array}{l}\text { complete variety of types of space: public (integrative), } \\
\text { public, semi-public, semi-private }\end{array}$ \\
\hline Identity & $\begin{array}{l}\text { cultural content is defined by: } \\
\text { - introduction of multiple public functions, } \\
\text { - dedicated cultural objects, } \\
\text { - commercial objects for the whole community of Rokiet- } \\
\text { nica town and Rokietnica community (administrative), } \\
\text { - creating currently nonexistent public spaces to accommo- } \\
\text { date social integration as well as local commercial activity. }\end{array}$ \\
\hline
\end{tabular}

a spindle and curved pseudo-axis connecting the northern access to the site with the southern one. Instead of closing the main street along which a quarter-like structure of the first project was organized, the second one forms a one-sided wall. The western side of the street close to the green stripe and recreation zone is limited with structures enclosing the spindle-like square, which is geometrically organized to visually mark the main cultural building, commercial hall, and arrangement of open, public space. The third concept refers more to modern ideas of new articulation of urban space. Series of connected interiors (squares, plazas) of diverse character, one representative, the other one recreational, next one filled with greenery, etc., intertwines spaces dedicated to pedestrians only with those for all users, including car-, bike- or bicycle users as well. 
Table 4: Conversion table: from a generic to particular case.

\begin{tabular}{|c|c|c|c|}
\hline $\begin{array}{l}\text { Generic case } \\
\text { sustainability } \\
\text { measures }\end{array}$ & $\begin{array}{l}\text { Sustainabil- } \\
\text { ity elements } \\
\text { in conversion }\end{array}$ & $\begin{array}{l}\text { Rokietnica case } \\
\text { sustainability } \\
\text { measures }\end{array}$ & Particular implementation \\
\hline $\begin{array}{l}>\text { availabil- } \\
\text { ity of distin- } \\
\text { guished urban } \\
\text { functions }\end{array}$ & $\begin{array}{l}\text { prioritizing } \\
\text { (PUD) } \\
\text { proportion } \\
\text { (PTS) }\end{array}$ & $\begin{array}{l}>\text { average to high den- } \\
\text { sity development } \\
>\text { variety of urban } \\
\text { forms of development }\end{array}$ & $\begin{array}{l}>3 \text { levels and up ( } 220 \mathrm{inh} . \\
\text { per ha min.) } \\
>\text { public squares and spaces, } \\
\text { various articulation of } \\
\text { typical buildings }\end{array}$ \\
\hline $\begin{array}{l}>\text { average to } \\
\text { optimum ac- } \\
\text { cessibility }\end{array}$ & $\begin{array}{l}\text { adaptability } \\
(\text { AUN) }\end{array}$ & $\begin{array}{l}>\text { high potential of } \\
\text { adaptability }\end{array}$ & $\begin{array}{l}\text { > integration of multiple } \\
\text { transportation modes and } \\
\text { connection routes, no- } \\
\text { barriers policy }\end{array}$ \\
\hline $\begin{array}{l}>\text { integrative } \\
\text { potential }\end{array}$ & $\begin{array}{l}\text { adaptability } \\
\text { (AUN) } \\
\text { integrity } \\
\text { (IUT) }\end{array}$ & $\begin{array}{l}>\text { high potential of } \\
\text { adaptability } \\
>\text { restoring dispersed } \\
\text { structure }\end{array}$ & $\begin{array}{l}>\text { clear distinction of public } \\
\text { and semi-public spaces } \\
>\text { connecting and gradually } \\
\text { bridging scales of sur- } \\
\text { rounding areas }\end{array}$ \\
\hline $\begin{array}{l}>\text { balanced } \\
\text { flexibility }\end{array}$ & $\begin{array}{l}\text { reduction } \\
\text { (RRC) } \\
\text { adaptability } \\
\text { (AUN) }\end{array}$ & $\begin{array}{l}\text { > providing basic ser- } \\
\text { vices at comfortable } \\
\text { distance, consolidat- } \\
\text { ing the use of infra- } \\
\text { structure, improving } \\
\text { urban space use (posi- } \\
\text { tive densification) } \\
>\text { high potential of } \\
\text { adaptability }\end{array}$ & $\begin{array}{l}>\text { multiple functions imple- } \\
\text { mented in site } \\
>\text { ability to change func- } \\
\text { tions, to adjust to chang- } \\
\text { ing requirements }\end{array}$ \\
\hline $\begin{array}{l}>\text { saturation of } \\
\text { nonresidential } \\
\text { functions }\end{array}$ & $\begin{array}{l}\text { adaptability } \\
\text { (AUN) } \\
\text { proportion } \\
\text { (PTS) }\end{array}$ & $\begin{array}{l}\text { > high potential of } \\
\text { adaptability } \\
>\text { saturation of non- } \\
\text { residential functions }\end{array}$ & $\begin{array}{l}>\text { capacity to absorb and/or } \\
\text { remove functions } \\
>\text { relatively high rate of ac- } \\
\text { companying functions } \\
>\text { introducing proportional } \\
\text { system of services and } \\
\text { commerce distribution }\end{array}$ \\
\hline $\begin{array}{l}>\text { reference } \\
\text { point (stability } \\
\text { node) + safety }\end{array}$ & $\begin{array}{l}\text { integrity } \\
\text { (IUT) } \\
\text { management } \\
+ \text { develop- } \\
\text { ment (CMD) }\end{array}$ & $\begin{array}{l}>\text { restoring dispersed } \\
\text { structure }\end{array}$ & $\begin{array}{l}>\text { adaptation of current men- } \\
\text { tal map of the area with } \\
\text { maintaining connections } \\
>\text { safety-oriented formation } \\
\text { of public areas } \\
>\text { monitoring of the develop- } \\
\text { ment }\end{array}$ \\
\hline $\begin{array}{l}\text { > visual } \\
\text { recognition: } \\
\text { spatial iden- } \\
\text { tity build. }\end{array}$ & $\begin{array}{l}\text { prioritizing } \\
\text { (PUD) } \\
\text { integrity } \\
\text { (IUT) }\end{array}$ & $\begin{array}{l}>\text { restoring dispersed } \\
\text { structure }\end{array}$ & $\begin{array}{l}>\text { spatial accentuation } \\
\quad \text { (dominants) } \\
>\text { clarity of spatial disposi- } \\
\text { tion }\end{array}$ \\
\hline
\end{tabular}


Currently, a report from a secondary inquiry has been elaborated, this time due to the implementation of participatory public GIS, and a second project has been selected to be redesigned according to findings resulting from both analyses and recognition of social preferences (Table 4).

\section{THE URBAN CENTER FOR THE IDENTITY: CONCLUSIONS}

When an identity is to be built or re-built, social acceptance as a minimal response, and social co-creation as optimal contribution to the process is required. After all, the identity is a construct and common notion, which must be adopted and positively received. Building spatial solutions in cruda radice eliminates the possibility to employ long tradition, or a historical background of the site, or of local community. Instead, an artificial, yet powerful process may be set in motion, but its artificiality bears the risk of social rejection or uncontrollable reinterpretation, or even misinterpretation.

The case of Rokietnica was, and still is, because it is an ongoing project, very informative and allows for studying peripheral agglomeration processes related to communities of 10,000 to 30,000 people. Not only does it disclose the relationship between generic process of suburban intervention and particular intervention, in which a nonexistent center (quarter, district, area) is to be established, it also reveals the influence on social understanding and perception, as well as its limitations, when it comes to this abstract concept of identity.

It became evident and was proven that several elements comprising the strategy of sustainable development of a local center require thorough control. There are more triggers initiating or contributing to shaping the spatial identity and all those require coordination. Unlike the case of Kiekrz, described a few years ago [12], Rokietnica employs practically all elements, not just two. The complexity of configuration of a central area forces to extend social participation in order to reflect the multifaceted nature of both social integration and spatial emanation of local community manifested in expected and unexpected, but accommodated constructions. The functional program must resonate within a community, but at the same time it must allow for change and retain some potential for future adaptations. The ideological program must convey at least partially familiar concepts that are understandable and rooted well in tradition and the continuity of people, regardless of generation or depth of ties with history of the place or the region. The structures must form clear boundaries for public, semi-public, and semi-private spaces with varied accentuation of courses leading through the area. The final result is generated by the process of consensual conclusion, not a power play and lobbying by open discourse and adjustment of social opinions, instead of imposed 'best' solution.

Getting local people involved in the process of formation of the center on a scale that is being tested in Rokietnica expands the timeline the image of the center is built in the imagination of the community. While everybody has the opportunity to know, or even to co-create, the space becomes 'domesticated', assimilated, and, regardless of differences between imagined and built, it is obvious that the built structure will be different from subjective, individual conceptualization. The story of the center begins humbly yet anchors itself in the common projection of not only physical space to come, but also social interactions, meaning transfers and 'social infrastructure'. Planners learn from this kind of application, how to facilitate the process, but not attempt to appropriate it; the results of the process should not be generated, but evolved, grown, moderated, and first of all discovered in situ. In this way, the project of identity will have the chance to become the identity itself, an artificial creation transformed into natural, absorbed in society. The research team hopes that these highlights and conclu- 
sions will be maintained in the remaining stages of intervention-in the final project selection and its construction, in several stages, for years to come.

\section{REFERENCES}

[1] Crowhurst Lennard, S.H. \& Lennard, H.L.,Livable Cities Observed, Gondolier Press: Carmel, pp. 7-8, 1995.

[2] Shortell, T. \& Krase, J., Place, space, identity: a spatial semiotics of the urban vernacular in global cities. In ESA Research Network Sociology of Culture Midterm Conference: Culture and the Making of Worlds, pp. 29, 2010.

[3] 8 - Urban and Spatial Planning and Design, Habitat III Issue Papers, Habitat III, United Nations Conference on Housing and Sustainable Urban Development, New York, p. 10, 2015.

[4] Ghafoor Al Ani, M.Q.A., He identity of place ... and memory of time ... define spacetime of human architecture. In Proceedings REAL CORP 2013, eds. M. Schrenk, V.V. Popovich, P. Zeile \& P. Elisei, Tagungsband:Rome, pp. 927-943, 2013.

[5] von Ungern-Sternberg, S., Ten guidelines for the planning and development of a new urban neighborhood. In Making Cities Livable, eds. S.H. Crowhurst Lennard, S. von Ungern-Sternberg \& H.L. Lennard, Gondolier Press: Carmel, pp. 237-243, 1997.

[6] Choudhary, B.K., Formation and (re)formation of spatial identities under globalization. Journal of Regional Development and Planning. 3(1), pp. 35-48, 2014.

[7] Op. cit., Ghafoor (2013: 934).

[8] Barelkowski, R., The Edge of the [dis]Order. In The Sustainable City VII. Urban Regeneration and Sustainability, Wessex Institute of Technology, eds. M. Pacetti, G. Passerini, C. A. Brebbia \& G. Latini, WIT Press: Southampton \& Boston, pp. 765-767, 2012.

[9] Kaczmarek, T. \& Wojcicki, M.,Uspolecznienie procesu planowania przestrzennego na przykladzie miasta Poznania, print, Instytut Geografii Spoleczno-Ekonomicznej i Gospodarki Przestrzennej, Uniwersytet im. Adama Mickiewicza w Poznaniu, pp. 8-9, 2015.

[10] Barelkowski, R., Strategies for identity of sustainable suburbs. In The Sustainable City IX. Urban Regeneration and Sustainability, Vol. 1, WIT Transactions on Ecology and the Environment, Vol. 191, Wessex Institute of Technology, eds. N. Marchettini, C.A. Brebbia, R. Pulselli \& S. Bastianoni, WIT Press: Southampton \& Boston, pp. 667-679, 2014. http://dx.doi.org/10.2495/sc140561

[11] Op. cit., Kaczmarek and Wojcicki (2015: 18-19).

[12] Op. cit., Barelkowski (2014: 679-680). 